\title{
Preliminary Strategic Environmental Assessment of the Great Western Development Strategy: Safeguarding Ecological Security for a New Western China
}

\author{
Wei Li $\cdot$ Yan-ju Liu $\cdot$ Zhifeng Yang
}

Received: 26 November 2008/ Accepted: 24 November 2011/Published online: 22 December 2011

(C) The Author(s) 2011. This article is published with open access at Springerlink.com

\begin{abstract}
The Great Western Development Strategy (GWDS) is a long term national campaign aimed at boosting development of the western area of China and narrowing the economic gap between the western and the eastern parts of China. The Strategic Environmental Assessment (SEA) procedure was employed to assess the environmental challenges brought about by the western development plans. These plans include five key developmental domains (KDDs): water resource exploitation and use, land utilization, energy generation, tourism development, and ecological restoration and conservation. A combination of methods involving matrix assessment, incorporation of expert judgment and trend analysis was employed to analyze and predict the environmental impacts upon eight selected environmental indicators: water resource availability, soil erosion, soil salinization, forest destruction, land desertification, biological diversity, water quality and air quality. Based on the overall results of the assessment, countermeasures for environmental challenges that emerged were raised as key recommendations to ensure ecological security during the implementation of the GWDS. This paper is intended to introduce a consensusbased process for evaluating the complex, long term pressures on the ecological security of large areas, such as
\end{abstract}

\footnotetext{
W. Li $(\bowtie) \cdot$ Y. Liu $\cdot$ Z. Yang

State Key Laboratory of Water Environment Simulation, School of Environment, Beijing Normal University, No. 19, Xin Jie Kou Wai St., Haidian District, Beijing 100875, China

e-mail: weili@bnu.edu.cn

Y. Liu

e-mail: lyjbnu@yahoo.cn

Z. Yang

e-mail: zfyang@bnu.edu.cn
}

western China, that focuses on the use of combined methods applied at the strategic level.

Keywords Strategic environmental assessment . Great Western Development Strategy · Western China . Key developmental domains - Ecological security . Safeguarding principle

\section{Introduction}

Internationally, Strategic Environmental Assessment (SEA) is defined as a systematic, on-going and comprehensive process for evaluating the environmental impacts of a policy, a plan or a program (PPPs) and identifying alternatives to them at the earliest appropriate stage (Fischer 2003; Noble and Christmas 2008). To date, systems of SEA have been established in both developing and developed countries to assess and modify proposed PPPs (Briffett and others 2003; Risse and others 2003). It is widely believed that SEA provides many benefits by embedding environmental considerations into the strategic and planning processes (Noble 2004; Randazzo and others 2008).

In China, an Environmental Impact Assessment (EIA) Law came into effect on 1 September 2003. The law adopted a form of SEA only at the level of plans (Plan Environmental Impact Assessment, PEIA) and incorporated an objective of rationalizing the development alternatives based on regional environmental carrying capacity and long term ecological security (Shen and others 2004; Zhu and others 2005; Bina 2008). From 2005 to 2008, the Chinese Ministry of Environmental Protection (MEP) had developed three rounds of PEIA demonstration projects, mainly for the typical regions and key sectors, and conducted a series of training courses for PEIA managerial staff and technicians. Based on the 
experience acquired from these pilot activities, the MEP issued a set of technical guidelines on PEIA and, as a milestone, issued the Ordinance of the PEIA, which has been in effect since 1 October 2009. All of these measures are attempts to set up a comprehensive management system and develop a set of techniques with the goal of ensuring the effectiveness of Chinese PEIA.

In the past two decades, many SEA projects have been performed on a variety of development plans or programs, including energy, transportation, industry, coastal zone, waste management, water or land use (Bao and others 2004; Chaker and others 2006; Barker 2006; Fischer and Gazzola 2006; Geneletti and others 2007; Salhofer and others 2007). A study of these projects reveals that a number of SEA methods and techniques have been employed, including systems analysis, analytic hierarchy process, cost-benefit analysis, compatibility analysis, cost effectiveness analysis, geographic information system (GIS) and Delphi technique (Say and Yücel 2006; Therivel and Walsh 2006; Chen and others 2009). However, despite the growing demand for SEA methodology, there is a widespread consensus regarding the lack of effective approaches, especially for the macro, large-scale SEAs at the policy level and beyond (Díaz and others 2001; Zhu and others 2005; Chaker and others 2006; Say and Yücel 2006; Noble and Christmas 2008; Bina 2008; Chen and others 2009; Sinclair and others 2009; Liu and others 2010).

The Great Western Development Strategy (GWDS) represents a huge commitment to progress in western China and is being undertaken in order to help narrow the economic gap between western China and the country's more developed eastern provinces. As a long term phased development strategy covering the period from 2000 to 2050, the GWDS would, without a doubt, produce cumulative environmental impacts or risks to significant ecological functions in the western region. In 2004, an SEA study of the first-phase GWDS was launched with technical support from the World Bank. In order to distinguish it from the more concrete SEA processes of the later decision processes under the GWDS, the first phase was referred to as a preliminary SEA. Its objectives were to formulate a general baseline description of the western environment, analyze the environmental impacts of the known GWDS plans, and provide suggestions for mitigating measures or alternatives as a means of facilitating the GWDS decision-making process.

The purpose of this paper is to introduce a consensusbased process for evaluating the sophisticated long term pressures on ecological security in a large area, such as western China, by employing combined methods at the strategic level. Some immediate countermeasures are recommended for protecting the valued environmental components as a means of safeguarding the ecological security of western China. In addition, the lessons learned are discussed to provide guidance to the next phase of the SEA for the later GWDS plans, and to improve the methods and processes for similar SEAs.

\section{Materials and Methods}

\section{General Background to Western China}

The western region covers 6.8 million $\mathrm{km}^{2}$, accounting for $71.4 \%$ of the entire terrestrial land area of China. Fifty out of the country's 55 minorities live in this area, and the region's total population accounts for $28.8 \%$ of China's total population. In 2003, western China contributed only $16.8 \%$ to China's gross domestic product (GDP) and the per capita GDP was only $68 \%$ of the national average. The low per capita GDP is partly explained by the fact that the western provinces have fewer urban residents than the rest of the country (29\% vs. $36 \%)$. A comparison of the per capita GDP for urban residents in the western provinces with that for urban residents elsewhere in China shows that the former is only $85 \%$ of the average for the latter (National Bureau of Statistics (NBS) 2004). Similar figures for rural residents were not available, but it is informative that in 2003 rural ownership of washing machines, refrigerators, bicycles and color TV sets was only $68,42,63$, and $82 \%$ of the national average, respectively (NBS 2004). Another contrasting statistic is the GDP per capita in Shanghai (the richest of all provinces and municipalities in China) with that of Guizhou (the poorest province in the western region and in all of China, except Tibet). Shanghai's GDP per capita is 13 times that of Guizhou's; in addition, the life expectancy is 12 years higher in the former than in the latter. In comparison with the other regions, the west has a higher percentage of land devoted to agriculture and a slower rate of industrial growth; but, on the positive side, more abundant natural resources. In addition, in both urban and rural areas, the main infrastructure and social elements, including transportation, culture, education, and pollution control facilities, are rather primitive.

Twelve provinces or municipalities are located in western China (Fig. 1). The region may be geographically split into three sub-areas: the southwestern (SW) sub-region (subtropical mountainous region), the northwestern (NW) sub-region (arid/semi-arid grassland), and the QinghaiTibet (QT) sub-region (high altitude plateau).

China's three best known rivers, the Yellow River, the Pearl River, and the Yangtze River, have their sources in the western China. The reservoir of the world's largest hydro-power engineering project, the Three Gorges Dam, which is situated in the middle reach of the Yangtze River, is also located in western China. In terms of ecological functions, western China contains seven out of the 
Fig. 1 Administrative scope and the typical ecological units of western China. Note. Southwest (SW) sub-region includes: $S C P$ Sichuan province; GZP Guizhou province; YNP Yunnan province; GXR Guangxi Zhuang autonomous region; $C Q M$ Chongqing municipality. Northwest (NW) sub-region includes: $S X P$ Shaanxi province; GSP Gansu province; $X J R$ Xinjiang Uygur autonomous region; $N X R$ Ningxia Hui autonomous region; IMR Inner Mongolia autonomous region. QinghaiTibet (QT) sub-region includes: $Q H P$ Qinghai province;

TAR Tibet autonomous region

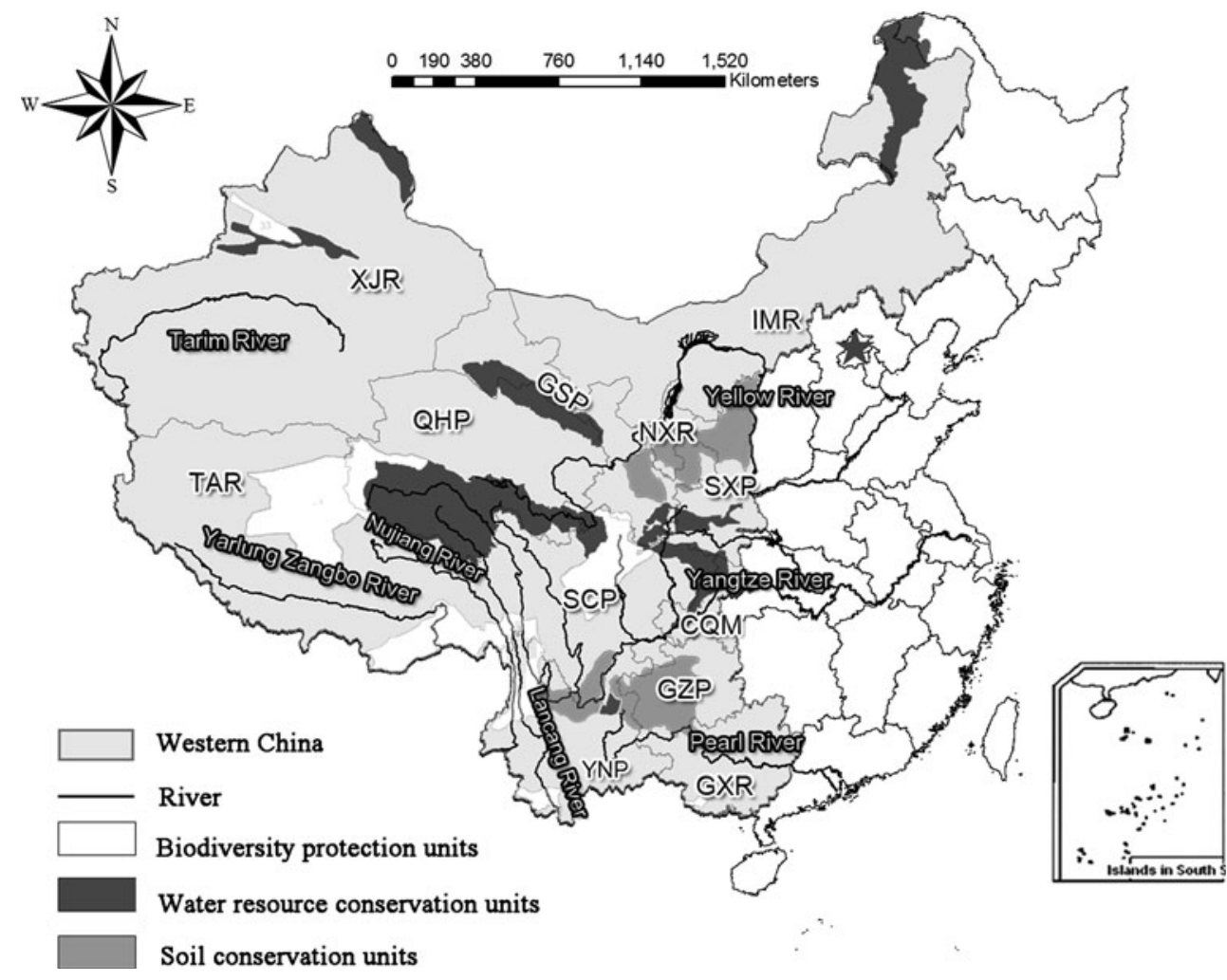

country's 17 internationally significant biodiversity hot spots and 28 out of 50 ecological function units of state significance, as classified by the Ecological Function Zoning of China (MEP 2007). Moreover, all of the western nature reserves at the provincial level and above account for $85 \%$ of the total area of national nature reserves. In addition, western China contains $70 \%$ of the state-level protected ecosystems and species, among which are the giant panda, the Yangtze River dolphin and the Yunnan snub-nose monkey. These three species are well known as being among in the world's endangered species.

Brief Description of the GWDS and Its DecisionMaking Framework

In order to shorten the economic gap between the western region and the rest of the country, the Western Development Office (WDO) of China's State Council has been designated as the head agency with responsibility for developing guiding policies and macro plans for the western development. In 1999, the WDO promulgated the 'Master Planning Outline for the Western Development'. The strategy contained in this Planning Outline represented a great commitment from the central government to speed up development of the west. As such, it was designed to boost socio-economic development, improve living conditions for the western minorities, and support environmental improvement during the period from 2000 to 2050 .
Under this long term strategic framework, a series of development policies, plans and planning processes for Phase I (2000-2010) have been successively initiated at both the central and local levels. The chief purpose has been to stimulate industrial development with primary focuses on mineral resource exploitation and refining, hydro-power generation, infrastructure improvement and ecological rehabilitation and conservation. The western provinces or municipalities may also make more concrete development plans under the GWDS framework based on their own needs.

Procedure of the SEA

Simply put, the purpose of the SEA described in this paper was to explore both direct and indirect environmental impacts from the key development plans and activities under the GWDS and predict the trends of the main indicators of environmental quality and ecological security. In accordance with the recommended Chinese PEIA procedures and international standards, a systematic work procedure was set up for the SEA of the GWDS decisionmaking process (Fig. 2).

\section{Methods Used in the SEA}

The methods used in the SEA were composed mainly of an assessment matrix, incorporation of expert judgment and 


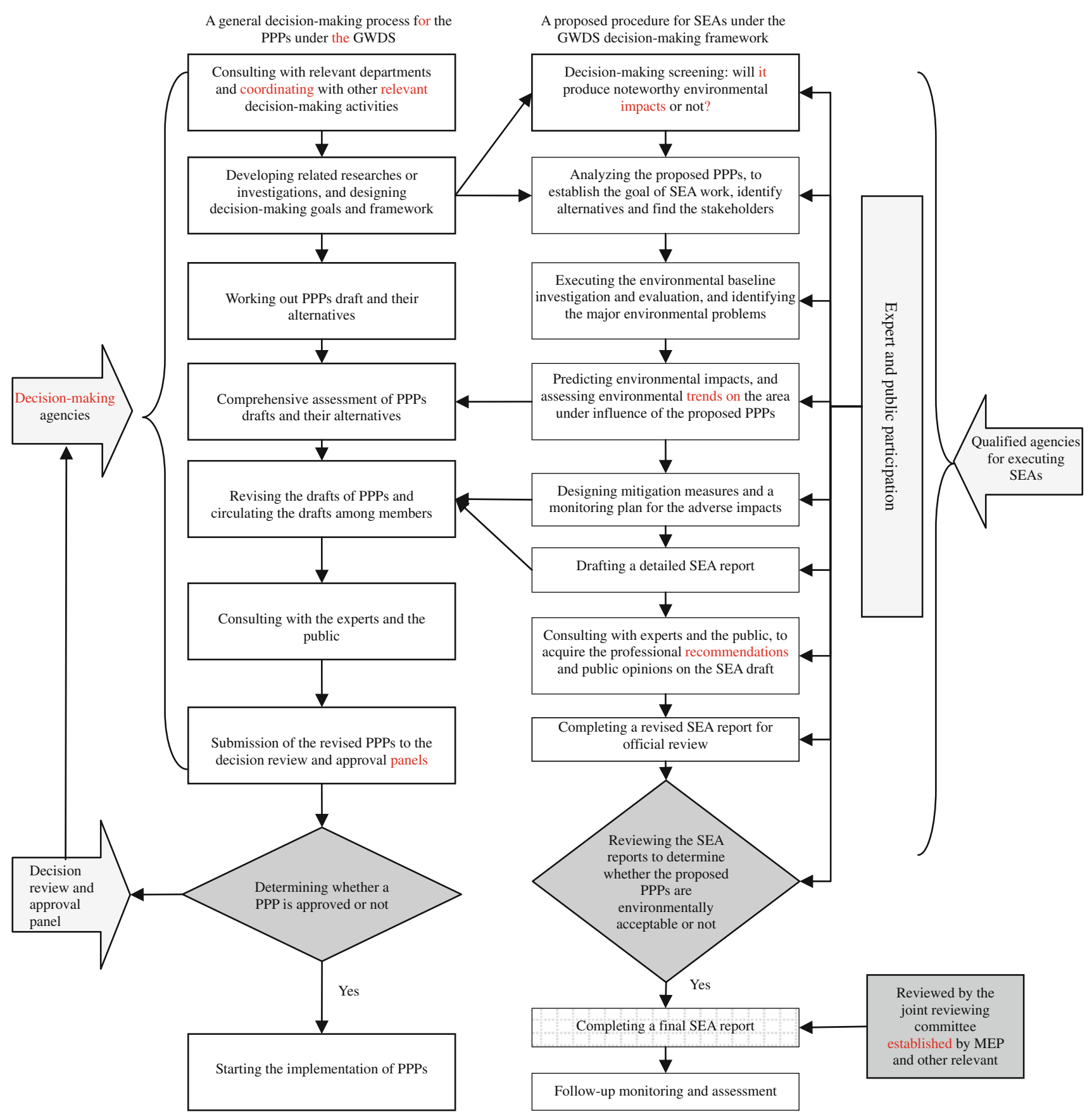

Fig. 2 Recommended SEA work procedures for the GWDS decision processes

trend analysis. An assessment matrix was used intensively throughout this SEA to identify and evaluate the environmental impacts stemming from the implementation of the GWDS development plans. Specifically, the impacts were identified and analyzed in three layers of western China: the entire regional level, the sub-region level of SW, NW and QT, and at the level of some key units with important ecological functions or environmental implications. In each layer, the key developmental domains (KDDs) were interlinked in matrix form with the eight environmental indicators: water resource availability (WRA), soil erosion (SE), soil salinization (SS), land desertification (LD), forest destruction (FD), water quality (WQ), air quality (AQ) and biological diversity (BD). The purpose was to assess the potential environmental impacts for each KDD jointly with the assistance of the independent experts and governmental officials through a series of brainstorming workshops or round table discussions.

Expert judgment was used in this case, which, to some extent, was similar to the familiar Delphi technique. 
Considering the special Chinese decision-making context, government officials and representatives of the People's Congress with strong professional experience were also involved in the SEA as management experts. Their involvement was to ensure a more integrated input and to appropriately tailor the recommendations that were to be incorporated into the decision-making and implementation processes of the GWDS. In addition, experts from several governmental departments were invited to participate, particularly from the member departments of WDO and the People's Congress. Universities, non-government organizations (NGOs) and research agencies contributed expertise and perspectives. The research agencies were mainly from the central government and provincial levels. Several independent environmentalists and international consultants also participated in the scoping seminars. More importantly, the Chinese task force that was involved in the UN Millennium Ecosystem Assessment (MEA) project joined the experts' meetings and provided much large scale information. The Chinese task force also provided interim results and findings, which, to a large extent, ensured a solid basis for the debates by the experts and, as a result, contributed to and informed their judgments on environmental challenges and future changes.

Trend analysis may help assessors predict future changes in the status of and impacts on receptors or targets when the available information or data are not enough to make a modeling analysis. In this project, trend analysis was used to make an overall judgment or to anticipate the likely future outcomes starting from the environmental situation for the base year of 2003. Meanwhile, as a complement to the matrix assessment, the method was also designed to deal with the uncertainty associated mainly with the plans or large activities that would be implemented in each province. Although a wide range of qualitative and quantitative factors were difficult to capture when the SEA was conducted, the chief criteria, as given in Table 1, were set up to make assessments of the present status of environmental quality and future changes of ecological problems in western China that were likely to be driven by the known PPPs of the GWDS.

\section{Process and Findings of the Assessment}

The purpose of the SEA process was to analyze the GWDS development plans at both the central and provincial levels, and to identify the KDDs with significant implications for both development and the environment. Once the KDDs were set up, the relevant development plans and their planned objectives and activities were analyzed to form the basis for identifying the potential environmental impacts. The overall environmental baseline of western China was measured by the ecological quality index (EQI) for each KDD and the environmental impacts were estimated for the eight environmental indicators mainly at the provincial level. Based on the overall assessment results, the recommendations were made to help ensure ecological security during the implementation of the GWDS.

\section{Identifying the KDDs of GWDS}

The released plans of the GWDS cover almost all important elements of social and economic development and environmental protection in the western region. The key tasks of these plans are to speed up infrastructure construction, strengthen protection and rehabilitation of the environment and water/land resources, reinforce the foundation for modern agriculture, update the industrial structure, and fully develop local tourism. Considering the vast area of western China and the diversified plans at the chief administrative levels, this SEA had to concentrate on the key areas, plans and problems to ensure effectiveness of its assessment. During a seminar that was designed to achieve consensus, five KDDs were identified: water resource exploitation and use, land utilization, energy generation, ecological restoration and conservation, and tourism development.

\section{Water Resource Exploitation and Use}

In order to improve living conditions and productivity in the western region, the plans for this KDD are aimed at promoting rational use and development of water resources. Objectives include optimizing allocation among users, increasing overall efficiency of water use, establishing infrastructure for water collection and conservation, developing new sources of water resources, and achieving sustainable water use. Furthermore, these plans are intended to strengthen the unified management of river basin resources, implement flood control measures, and strengthen reservoirs. Water resources in the upper reaches of the Yellow and Yangtze River drainage areas will receive intensified protection. The WQ of the Heihe River in Gansu Province (GSP) and the Tarim River in Xinjiang Uygur Autonomous Region (XJR) will be improved by raising treatment levels of the wastewater discharged into the two rivers. The strategy will also introduce market reforms and appropriate pricing mechanisms to improve water use efficiency, and implement diversified ecological compensation mechanisms to encourage watershed conservation.

\section{Land Utilization}

Though the terrestrial area of western China is huge, the available land for construction, living and farming is still limited, less than half of the total. Land use plans have the 
Table 1 Classified environmental standards employed in the SEA of the GWDS

\begin{tabular}{|c|c|c|c|c|}
\hline \multirow[t]{2}{*}{ Environ. indicators } & \multicolumn{2}{|c|}{ Current situation } & \multicolumn{2}{|c|}{ Future scenario } \\
\hline & Grades & Standards for determining the grades & Trends & Criteria for predicting the trends \\
\hline \multirow{3}{*}{$\begin{array}{l}\text { Water resource availability } \\
\text { (WRA) }\end{array}$} & I & Use rate is less than $10 \%$. & $\nearrow$ & Use rate is likely to decrease \\
\hline & II & Use rate is between 10 and $40 \%$ & $\rightarrow$ & Use rate is likely to be stable \\
\hline & III & Use rate is over $40 \%$ & $\searrow$ & Use rate is likely to increase \\
\hline \multirow[t]{3}{*}{ Soil erosion (SE) } & I & \multirow{3}{*}{$\begin{array}{l}\text { This value is determined mainly by expert } \\
\text { judgments and from literature surveys }\end{array}$} & $\nearrow$ & The level of soil erosion is likely to decrease \\
\hline & II & & $\rightarrow$ & The level of soil erosion is likely to be stable \\
\hline & III & & $\searrow$ & The level of soil erosion is likely to increase \\
\hline \multirow[t]{3}{*}{ Soil salinization $^{\mathrm{a}}(\mathrm{SS})$} & I & $\begin{array}{l}\text { Favorable reclamation quality with the } \\
\text { value between } 0.5 \text { and } 1.0 \text {, except in } \\
\text { IMR where the values are between } 0.1 \\
\text { and } 0.3\end{array}$ & $\nearrow$ & Level of salinization is likely to decline \\
\hline & II & $\begin{array}{l}\text { Impaired reclamation quality with the } \\
\text { value between } 1.0 \text { and } 1.5 \text {, except in } \\
\text { IMR where the values are between } 0.3 \\
\text { and } 0.7\end{array}$ & $\rightarrow$ & Level of salinization is likely to be stable \\
\hline & III & $\begin{array}{l}\text { Poor reclamation quality with the value } \\
\text { between } 1.5 \text { and } 2.0 \text {, except in IMR } \\
\text { where the values are between } 0.7 \text { and } \\
1.0\end{array}$ & $\searrow$ & Level of salinization is likely to increase \\
\hline \multirow[t]{9}{*}{ LD } & I & No desertification & $\nearrow$ & State remains without this problem. \\
\hline & II & Vegetation coverage is over $30 \%$ & $\rightarrow$ & Level of desertification is likely to be stable \\
\hline & & Sand movement is less prominent & & \\
\hline & & $\begin{array}{l}\text { Land surface covered by basically stable } \\
\text { dunes }\end{array}$ & & \\
\hline & $\mathrm{II}^{\mathrm{b}}$ & $\begin{array}{l}\text { Vegetation coverage is between } 10 \text { and } \\
30 \% \text { with more than } 750 \text { individual } \\
\text { trees or bushes per hectare on average }\end{array}$ & & \\
\hline & & $\begin{array}{l}\text { Sand drift is controlled by plant } \\
\text { communities, but sand movement } \\
\text { ripples are prevailing on the dunes }\end{array}$ & & \\
\hline & III & Vegetation coverage is less than $10 \%$ & $\searrow$ & Level of desertification is likely to be raised \\
\hline & & $\begin{array}{l}\text { Mobile sand sheets and the denuded dune } \\
\text { areas are inter-distributed }\end{array}$ & & \\
\hline & & $\begin{array}{l}\text { Sand dunes are stabilized with non- } \\
\text { biological measures }\end{array}$ & & \\
\hline \multirow[t]{3}{*}{ Forest destruction (FD) } & I & $\begin{array}{l}\text { Very good quality, with intact primary } \\
\text { forests }\end{array}$ & $\nearrow$ & Forest quality is likely to improve \\
\hline & II & $\begin{array}{l}\text { Good quality, with threats requiring } \\
\text { control }\end{array}$ & $\rightarrow$ & Forest quality is likely to be stable \\
\hline & III & $\begin{array}{l}\text { Poor quality, with widespread losses of } \\
\text { primary and mature forests }\end{array}$ & $\searrow$ & Forest quality is likely to worsen \\
\hline \multirow[t]{3}{*}{ Water quality (WQ) } & I & $\begin{array}{l}\text { Annual average of WQ of the main rivers } \\
\text { in a western province or municipality or } \\
\text { autonomous region is level I or II } \\
\text { measured by the CNSWQS }\end{array}$ & $\nearrow$ & The WQ of main rivers is likely to improve \\
\hline & II & $\begin{array}{l}\text { Annual average of WQ of the main rivers } \\
\text { in a western province or municipality or } \\
\text { autonomous region is level III or IV } \\
\text { measured by the CNSWQS }\end{array}$ & $\rightarrow$ & The WQ of main rivers is likely to be stable \\
\hline & III & $\begin{array}{l}\text { Annual average of WQ of the main rivers } \\
\text { in a western province or municipality or } \\
\text { autonomous region is level V or below } \\
\text { measured by the CNSWQS }\end{array}$ & $\searrow$ & The WQ of main rivers is likely to worsen \\
\hline
\end{tabular}


Table 1 continued

\begin{tabular}{|c|c|c|c|c|}
\hline \multirow[t]{2}{*}{ Environ. indicators } & \multicolumn{2}{|c|}{ Current situation } & \multicolumn{2}{|c|}{ Future scenario } \\
\hline & Grades & Standards for determining the grades & Trends & Criteria for predicting the trends \\
\hline \multirow[t]{3}{*}{ Air quality (AQ) } & I & $\begin{array}{l}\text { Annual average of } \mathrm{API}^{\mathrm{d}} \text { of the capital city } \\
\text { in a western province or municipality or } \\
\text { autonomous region is } \leq 50\end{array}$ & $\nearrow$ & The AQ is likely to improve \\
\hline & II & $\begin{array}{l}\text { Annual average of API of the capital city } \\
\text { in a western province or municipality or } \\
\text { autonomous region is } 50<\text { API } \leq 100\end{array}$ & $\rightarrow$ & The AQ is likely to be stable \\
\hline & III & $\begin{array}{l}\text { Annual average of API of the capital city } \\
\text { in a western province or municipality or } \\
\text { autonomous region is }>100\end{array}$ & $\searrow$ & The AQ is likely to worsen \\
\hline \multirow[t]{3}{*}{ Biological diversity (BD) } & I & $\begin{array}{l}\text { The value is determined through expert } \\
\text { judgment }\end{array}$ & $\nearrow$ & $\begin{array}{l}\text { Species abundance/eco-services are likely } \\
\text { to increase }\end{array}$ \\
\hline & II & & $\rightarrow$ & $\begin{array}{l}\text { Species abundance/eco-services are likely } \\
\text { to be stable }\end{array}$ \\
\hline & III & & $\searrow$ & $\begin{array}{l}\text { Species abundance/eco-services are likely } \\
\text { to decline }\end{array}$ \\
\hline
\end{tabular}

a Soil salinization (SS) is simply measured by total salt content (\%) in top $30 \mathrm{~cm}$ of soil

b The classifications of LD are based upon the criteria given in the China Desertification Information Network

${ }^{c}$ CNSWQS is the China National Surface Water Quality Standard (GB3838-2002). There are 24 basic item indexes in the Standard, such as COD, biochemical oxygen demand (BOD), ammonium nitrogen $\left(\mathrm{N}-\mathrm{NH}_{3}\right)$. Water quality is divided into five levels according to its purpose for use and protection targets

d API is the abbreviation for the air pollution index. It is a composite index depicting the aggregate level of the three major air pollutants in China; namely, $\mathrm{SO}_{2}$, nitrogen dioxide $\left(\mathrm{NO}_{2}\right)$, and respirable suspended particulates $\left(\mathrm{PM}_{10}\right)$. The higher the index value, the higher the air pollution levels. It is divided into five grades: very good (API $\leq 50)$, good $(50<$ API $\leq 100)$, slight pollution $(100<$ API $\leq 200)$, moderate pollution (200 API $\leq 300)$, and serious pollution (API > 300)

I: No or few environmental problems, with a good potential or capacity for future use and development

II: Moderate environmental problems, with limited capacity for development; mitigation of environmental pressures is needed

III: Significant environmental problems; immediate actions are required to reduce environmental pressures

Three broad scenarios: $\searrow$ environmental deterioration; $\nearrow$ environmental improvement; $\rightarrow$ stable environmental status

following objectives: (i) to make available required construction land for infrastructure developments while, at the same time, protecting the agricultural/cultivatable land; (ii) to return the cultivatable land to forest and grassland in the ecologically fragile areas; (iii) to protect and ensure sustainability of the cultivatable land. In order to allow space for cultivation on high-quality farmland in the western region, the establishment of forests, fruit plantations and animal husbandry zones will be a priority in arid zones, mountain areas, and abandoned lands in the western region.

\section{Energy Generation}

Energy sector plans are designed to take advantage of the region's energy reserves and to develop the West as an energy base for the rest of China with the aid of west-to-east power transmission projects. The plans are intended to strengthen oil and gas exploration capacity as part of a wider state energy strategy. Other objectives include improving industry structure and addressing energy efficiency with the use of advanced technologies for maximizing energy capture and efficiency. While power distribution will be upgraded at the local level, the structure of power grids at the national level will be improved with the construction of three high-voltage grids (north, middle and south) to transport electricity generated in the West to eastern end users.

\section{Ecological Rehabilitation and Conservation}

The GWDS strategy includes extensive plans for reestablishing large areas of forest and grassland vegetation. Furthermore, it includes the provision of more effective protection for rare and endangered animal and plant species. A series of nature reserves covering an area of around six million hectares will be established and, within five years, the region will have over 200 nature reserves, including $40 \mathrm{key}$ state level reserves covering a total area of approximately 45 million ha.

Forest management will be strengthened. Forest and grassland vegetation will be restored with large-scale protection and planting schemes, a focus will be reforestation of mountain areas and abandoned fields. Forestations will be implemented through 'grain for green' projects, where farmers are compensated for returning farmland to forest 
and grassland. Natural forests and grasslands will receive extra protection, and destruction or unregulated exploitation will be banned. Threats to grassland habitats, such as cattle grazing, will be managed (e.g., by promoting rotation grazing), and grassland for agriculture will be controlled.

\section{Tourism Development}

The region spans a huge landmass with dramatic landscapes, abundant rivers, lakes, mountains, biodiversity, and many marvelous natural sights. Furthermore, the region has a rich cultural heritage with many important sites and over 50 different ethnic groups offering a wide range of customs and traditions. The objectives of tourism development plans are to fully utilize the abundant natural and cultural attractions in western China. The tourism industry will be established as a key development objective and tourism should become a pillar industry in the region. Appropriate infrastructure will be developed, focusing on transportation needs, use of scenic spots, and protection of key locations. The Western Tourism Investment Plans, compiled by the National Tourism Administration (NTA), National Development and Reform Commission (NDRC) and WDO, have set out the main tourist attractions to be developed.

Investigating Environmental Baseline of Western China

It took about 1 year to build up the environmental baseline for western China. This was done by collecting and processing information and data from statistical yearbooks, environmental bulletins, remote sensing findings, relevant research reports and other sources. A number of important social, economic, and ecological aspects of western China are shown in Table 2.

\section{Evaluating the Overall Ecological Quality}

Much of the environment and the natural resource base in western China is vulnerable to human pressure and can be easily degraded. These environmental issues are not independent, which means that it is hard to address one problem at a time. A brief description of the main ecological issues is summarized in the following paragraphs based on the information and findings acquired from related studies and the scientific literature.

Water Shortage and Over-Exploitation While the SW and QT sub-regions have a relative abundance of water, provinces in the NW sub-region suffer severe water shortage and have growing problems with its availability and pollution.

- SW sub-region: Water resources are relatively abundant; however, in karst landscapes (high mountains and deep valleys) it is difficult to construct irrigation facilities and to utilize abundant runoff water.

- NW sub-region: This area suffers from very severe water deficiencies, annual precipitation is less than

Table 2 Main baseline statistics for the western provinces

\begin{tabular}{|c|c|c|c|c|c|c|c|c|c|}
\hline \multirow[t]{2}{*}{ Sub-regions } & \multirow[t]{2}{*}{ Provinces } & \multirow{2}{*}{$\begin{array}{l}\text { Population } \\
\text { (million) }\end{array}$} & \multirow{2}{*}{$\begin{array}{l}\text { Land area } \\
\text { (thousands } \\
\text { of } \mathrm{km}^{2} \text { ) }\end{array}$} & \multicolumn{2}{|c|}{ Water resources } & \multicolumn{2}{|c|}{ Nature reserves } & \multicolumn{2}{|l|}{ Forest } \\
\hline & & & & $\begin{array}{l}\text { Amount } \\
\left(\mathrm{km}^{3}\right)\end{array}$ & $\begin{array}{l}\text { Per capita } \\
\left(\mathrm{m}^{3}\right)\end{array}$ & Number & $\begin{array}{l}\text { Area } \\
\left(\mathrm{km}^{2}\right)\end{array}$ & $\begin{array}{l}\text { Area } \\
\left(\mathrm{km}^{2}\right)\end{array}$ & $\begin{array}{l}\text { Coverage } \\
\text { rate }(\%)\end{array}$ \\
\hline \multirow[t]{6}{*}{ SW } & CQM & 31.3 & 82.4 & 59.1 & 1,887 & 46 & 8,660 & 22,363 & 27.14 \\
\hline & SCP & 87.0 & 485.0 & 259.0 & 2,977 & 120 & 70,770 & 135,510 & 27.94 \\
\hline & GZP & 38.7 & 141.0 & 915.6 & 23,658 & 107 & 8,090 & 36,731 & 26.05 \\
\hline & YNP & 43.7 & 394.0 & 169.9 & 3,889 & 186 & 35,500 & 128,732 & 32.67 \\
\hline & GXR & 48.6 & 236.7 & 190.1 & 3,912 & 67 & 14,810 & 81,666 & 34.50 \\
\hline & Sub-total & 249.3 & 1339.1 & 1593.6 & 6,392 & 526 & 137,830 & 405002 & 30.24 \\
\hline \multirow[t]{6}{*}{ NW } & SXP & 36.9 & 205.8 & 57.5 & 1,557 & 32 & 70,770 & 59,203 & 28.77 \\
\hline & GSP & 26.0 & 454.4 & 24.7 & 951 & 47 & 87,860 & 21,741 & 4.78 \\
\hline & NXR & 5.8 & 66.4 & 1.2 & 212 & 12 & 4,920 & 1,464 & 2.20 \\
\hline & XJR & 19.3 & 1660.0 & 92.0 & 4,767 & 26 & 215,290 & 17,837 & 1.07 \\
\hline & IMR & 23.8 & 1183.0 & 49.6 & 2,082 & 183 & 148,900 & 147,485 & 12.47 \\
\hline & Sub-total & 111.8 & 3569.6 & 225.0 & 2,012 & 300 & 527,740 & 247730 & 6.94 \\
\hline \multirow[t]{3}{*}{ QT } & QHP & 5.3 & 722.3 & 63.5 & 11,975 & 8 & 206,080 & 3,088 & 0.43 \\
\hline & TAR & 2.7 & 1220.0 & 475.7 & 176,189 & 15 & 408,730 & 40,815 & 3.35 \\
\hline & Sub-total & 8.0 & 1942.3 & 539.2 & 67,398 & 23 & 614,810 & 43903 & 2.26 \\
\hline \multicolumn{2}{|c|}{ Total for entire western region } & 369.1 & 6851.1 & 2357.8 & 6,388 & 849 & $1,280,380$ & 671,777 & 10.17 \\
\hline
\end{tabular}

Source. China Statistical Yearbook (2004), NBS 
$400 \mathrm{~mm}$. The use of water, especially for irrigation, has increased over the last few decades, even though both surface and groundwater resources are very limited. As a result, groundwater resources are seriously overexploited, which has, in turn, produced large underground funnels in some areas.

- QT sub-region: In general, there is no water shortage in the high plateau, and WQ is good, especially in Tibet. However, in recent years human activities, such as the building of dams, have led to a lowering of the water table, a shrinking of water levels in lakes and a drying up of some wetland areas.

Land Degradation Land degradation has been caused by three main processes: soil erosion, desertification and salinization.

Soil erosion: The loss of topsoil is an irreversible process that places severe limits on the agricultural production capacity of the land. According to a remote sensing analysis project, $60 \%$ of western China is affected by soil erosion (Fig. 3). Some of the most serious examples in the world have occurred in the semi-arid Loess Plateau (MEP and SBSM 2002).

Desertification: Land desertification (LD) in China, which is among the worst in the world, is very serious in the arid and semi-arid NW sub-region and in the high plateau region. The three provinces with the largest areas of desertification are XJR, Inner Mongolia Autonomous Region (IMR) and GSP. The affected land is 46.3, 30.0, and $25.7 \%$ of the total area in each respective province (Fig. 3). Apart from climate, the most important factors influencing desertification are certain types of land use and overly intense land use practices.

Salinization: Salinization is a serious problem in the NW sub-region. The total area affected in this part of western China is $34,500 \mathrm{~km}^{2}$. Soil salinization is caused by inappropriate irrigation and farming practices. This situation is extremely serious in the Hexi area in GSP, the Tarim Basin and the southern edge of Junggar Basin in XJR; the Qaidam Basin in Qinghai Province (QHP); the Hetao area in IMR, the Yinchuan plain in Ningxia Hui Autonomous Region (NXR); and the Weinan-Dingbian belt in Shaanxi Province (SXP).

Forest Deterioration Overall levels of forest cover are increasing in all western provinces except Tibet. However, levels of virgin forest are actually declining because of the long-term conversion of forested land into cultivatable land, development of water resources, illegal logging activities, and fuel wood collection in the impoverished remote areas.
Environmental Pollution The pollution categories considered here are water and air pollution. Water pollution prevention and control is not well enforced in western China. For example, municipal wastewater treatment rates range from $3.6 \%$ in Guizhou Province (GZP) to $60 \%$ in Yunnan Province (YNP). In 2003, the total volume of wastewater discharged in western China was 48.2 billion tons. The SW sub-region, which has generally the highest rates of population increase and water use, also has the highest levels of wastewater, chemical oxygen demand (COD) and ammonium nitrogen $\left(\mathrm{N}-\mathrm{NH}_{3}\right)$ discharges.

Compared with the central and eastern areas of China, air emissions are not large in absolute terms. But in some areas where industries are concentrated, the air pollution is very serious. For example, the cities of Urumchi, Lanzhou, and Chongqing are all among the world's top 10 cities in terms of air pollution, bringing serious health impacts to local citizens. Sulfur is a major component of the region's air pollution problems. The emission of sulfur dioxide $\left(\mathrm{SO}_{2}\right)$ from coal-fired power plants accounts for $68 \%$ of the total emissions. These emissions along with the climate, topography, and landscape characteristics result in a relatively high level of acidity in the rain that falls in the region. Around $170,000 \mathrm{~km}^{2}$ of land area, mostly in Sichuan Province (SCP), Guangxi Zhuang Autonomous Region (GXR), GZP and YNP are affected by the acid rain.

Loss of Biodiversity and Ecosystem Services With economic expansion, biodiversity and ecosystems in western China have been experiencing accelerated degradation in some areas because of fragile ecological conditions and unenlightened development. For example, in XJR, the protected coverage of the local plant Tetraena mongolica Maxim has been reduced by about 300 hectares because of an invasive species introduced by a farm in the vicinity. Recently, the region's biodiversity attractions are drawing a growing number of tourists. The rapidly increasing tourism intensity is threatening crucial wildlife habitats, and, in turn, is accelerating the loss of rare or endangered species.

The overall ecological status of western China was evaluated by using the EQI, an index recommended by the China Environmental Monitoring Center Station (CEMCS) as a uniform measure of ecological quality. The EQI is estimated with the aid of five sub-indexes of organism abundance (OB), vegetation coverage (VC), river network density (RND), soil deterioration (SD) and pollution load (PL). The formula for EQI is given as follows:

$$
\begin{aligned}
\mathrm{EQI}= & 0.3 \times \mathrm{OB}+0.2 \times \mathrm{VC}+0.25 \times \mathrm{RND}+0.15 \\
& \times(100-\mathrm{SD})+0.1 \times(100-\mathrm{PL})
\end{aligned}
$$


Fig. 3 Soil erosion and desertification of the arable lands and grasslands in western China
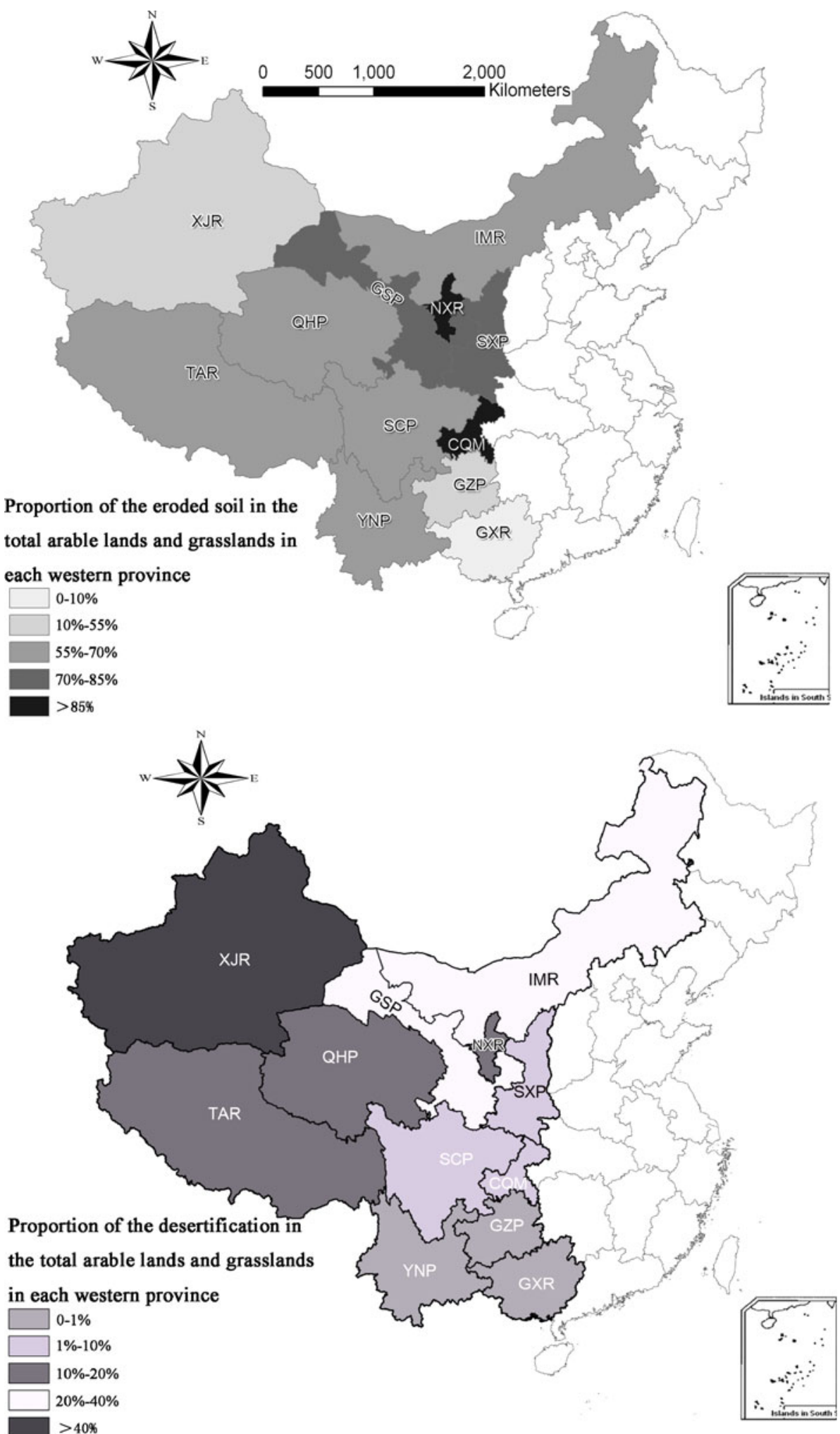

Figure 4 shows the ecological quality results as determined by the EQI, for the western regions and provinces or municipalities. It can be seen that the ecological quality of the SW sub-region as a whole is better than that for both the NW and QT sub-regions. 
Fig. 4 Ecological quality evaluation by EQI of the provinces in western China. Note The definitions and evaluation formulas of EQI are given in "Evaluating the overall ecological quality" section

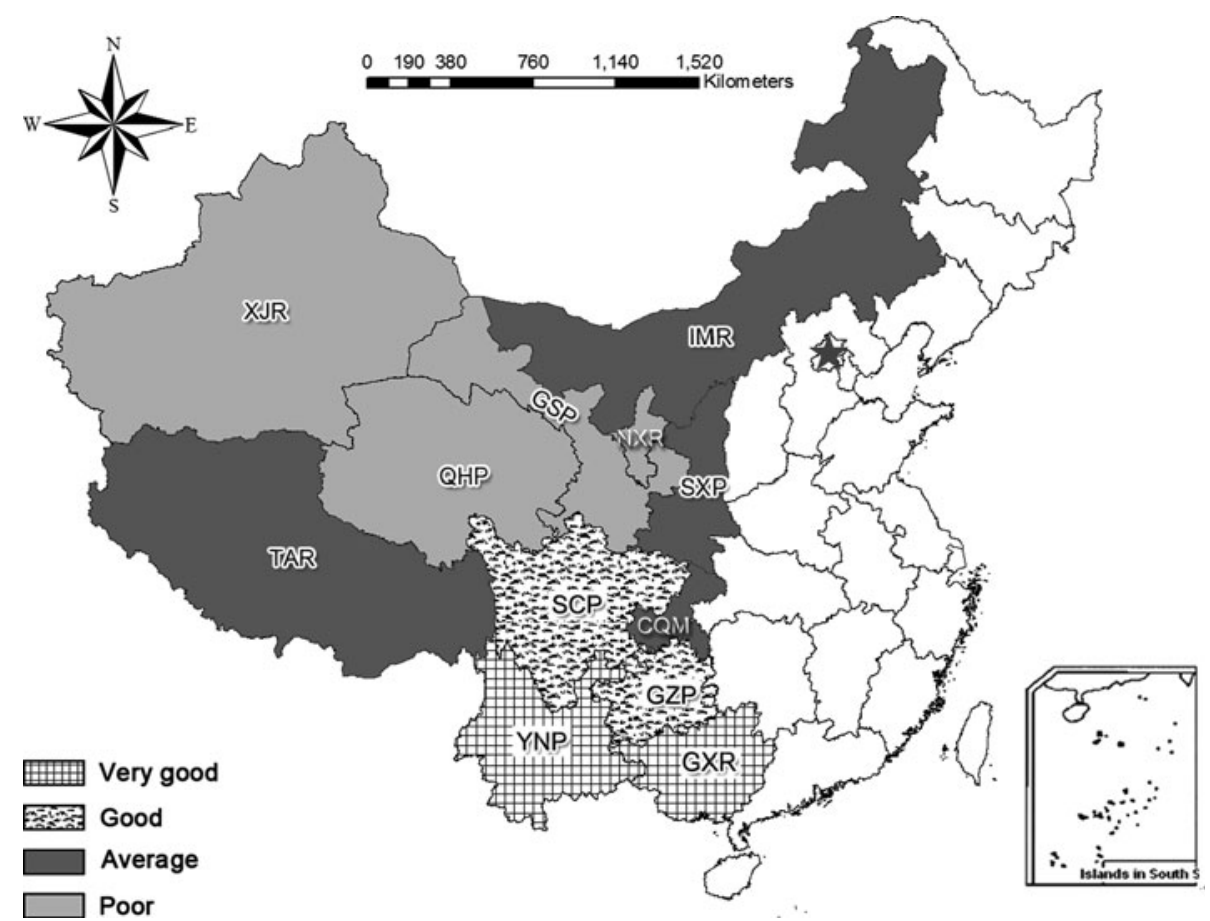

Investigating the Environmental Problems at the Provincial Level

The prominence of environmental problems outlined above varies across each province consistent with the environmental conditions specific to each area. Based on the eight environmental indicators, the environmental features for each province were investigated, and summarized as shown in Table 3.

The findings indicate that there are significant differences in critical issues across the western sub-regions. The problems of water availability and land degradation are more serious in the NW sub-region, while biodiversity loss and environmental pollution are relatively more severe in the provinces of the SW sub-region.

\section{Assessing Environmental Impacts of the KDDs}

Based upon intensive literature surveys and brainstorming seminars, the potential environmental impacts of the five KDDs were assessed from the perspective of the criteria given in Table 1 . This assessment was done mainly at the sub-regional levels.

\section{Water Resource Development Plans}

In their current form, water resource plans would have negative consequences for almost all areas, including the stressed NW sub-region. In the NW sub-region, soil erosion will be ameliorated, but salinization and desertification may become worse.
Wastewater treatment levels are continuously improving in western cities, but the construction of water conservation and hydroelectric projects will impact WQ.

The current plans call for many new dams, especially in the SW sub-region. Dam construction will impact the habitats in flooded and downstream areas, and impede the passage of migratory aquatic species (Li and others 2003). For example, the construction of key water control projects, such as the Zipingpu dam in SCP, will have a negative impact on the migration and survival of some indigenous fish species. This construction will also affect the natural flow of water farther downstream.

\section{Land Utilization Plans}

Land utilization plans are judged to be predominantly negative. These plans have implications across all aspects of the environment, particularly for soil erosion, deforestation and biodiversity. Expansion of agricultural activities will possibly threaten the local water balance and cause increased desertification. In the longer term, urban and industrial expansion will place direct (e.g., through increased water demand) and indirect (e.g., through reduced watershed vegetation cover) pressures on water sustainability.

Railway or highway construction and mining activities in areas where water is scarce will lead to local loss of surface vegetation, and deterioration in topsoil quality. In many cases, animals may become locally extinct because of habitat scarcity and food shortage. Furthermore, most remaining animals will be isolated due to habitat 
Table 3 Environmental features of each western province based on the eight environmental indicators

\begin{tabular}{|c|c|c|c|}
\hline $\begin{array}{l}\text { Sub- } \\
\text { regions }\end{array}$ & $\begin{array}{l}\text { Province, } \\
\text { municipality, } \\
\text { autonomous region }\end{array}$ & $\begin{array}{l}\text { Environmental } \\
\text { indicators }\end{array}$ & Environmental baseline levels \\
\hline \multirow[t]{40}{*}{ SW } & \multirow[t]{8}{*}{ CQM } & Overall status & The ecological quality is good as a whole \\
\hline & & WRA & $1,887 \mathrm{~m}^{3}$ per capita. Yangtze and Jialing rivers provide abundant water resources \\
\hline & & SE & Soil erosion occurs in as much as $44 \%$ of the total area \\
\hline & & SS & No soil salinization problem \\
\hline & & LD & Desertification is low, occurring in less than $2.0 \%$ of the total area \\
\hline & & FD & Forest cover is $36 \%$, on average, of the total area, and is quite stable \\
\hline & & WQ/AQ & Urban sprawl causes serious air and water pollution in the area \\
\hline & & $\mathrm{BD}$ & 46 nature reserves, with a total area of $8,660 \mathrm{~km}^{2}$, status is good. \\
\hline & \multirow[t]{8}{*}{$\mathrm{SCP}$} & Overall status & The ecological quality is fairly good as a whole \\
\hline & & WRA & 258,980 million $\mathrm{m}^{3}$ of water resources and $2,977 \mathrm{~m}^{3}$ per capita \\
\hline & & SE & $\begin{array}{l}40 \% \text { of the land }\left(194,000 \mathrm{~km}^{2}\right) \text { is prone to erosion. Soil \& water loss occurs in around } \\
44 \% \text { of the total area }\end{array}$ \\
\hline & & SS & No salinization problem as a whole \\
\hline & & $\mathrm{LD}$ & The soil quality is good, with a lower desertification rate \\
\hline & & FD & Forest cover is $23.5 \%$ of the total area, with an annual growth rate of $2 \%$ \\
\hline & & WQ/AQ & $\begin{array}{l}\text { High pollution levels with annual } \mathrm{COD} \text { and } \mathrm{SO}_{2} \text { emissions of } 0.94 \text { and } 1.2 \text { million tons, } \\
\text { respectively }\end{array}$ \\
\hline & & BD & Good biodiversity with 120 nature reserves, with a total area of $70,770 \mathrm{~km}^{2}$ \\
\hline & \multirow[t]{8}{*}{ GZP } & Overall status & The ecological quality is not good as a whole \\
\hline & & WRA & $\begin{array}{l}\text { The river network density is very high, with } 23,658 \mathrm{~m}^{3} \text { water resources per capita, on } \\
\text { average }\end{array}$ \\
\hline & & SE & $\begin{array}{l}\text { The losses of water and soil are severe, with soil erosion occurring in } 44 \% \text {, on average, } \\
\text { of the total area }\end{array}$ \\
\hline & & SS & No salinization problem \\
\hline & & LD & Poor soil quality with slight rocky desertification \\
\hline & & FD & $\begin{array}{l}\text { Forest cover is } 20.8 \% \text { of the total area totaling } 36,731 \mathrm{~km}^{2} \text {, and the annual growth rate } \\
\text { is about } 5 \% \text {, on average }\end{array}$ \\
\hline & & WQ/AQ & $\begin{array}{l}\text { The AQ is poor in cities, with the largest } \mathrm{SO}_{2} \text { emission of } 1.45 \text { million tons among all } \\
\text { of the provinces in western China }\end{array}$ \\
\hline & & $\mathrm{BD}$ & $\begin{array}{l}\text { Abundant biodiversity with } 107 \text { nature reserves, with an area of } 8,090 \mathrm{~km}^{2} \text {, but } \\
\text { biodiversity loss is a depressing problem }\end{array}$ \\
\hline & \multirow[t]{8}{*}{ YNP } & Overall status & The ecological quality is good \\
\hline & & WRA & $\begin{array}{l}\text { It is rich in water resources, with a total volume of } 169,940 \text { million } \mathrm{m}^{3} \text {. The per capita } \\
\text { level is } 3,889 \mathrm{~m}^{3}\end{array}$ \\
\hline & & SE & The soil and water loss occurs in as much as $37 \%$ of the total area \\
\hline & & SS & No salinization problem as a whole \\
\hline & & LD & The desertification occurs in merely $0.2 \%$ of the total area \\
\hline & & FD & $\begin{array}{l}\text { Has the highest level of vegetation cover among the western provinces. The forest cover } \\
\text { is } 34 \% \text { of the total area, and is increasing by } 3 \% \text { annually }\end{array}$ \\
\hline & & WQ/AQ & Relatively low emission loads to the water and air environments \\
\hline & & $\mathrm{BD}$ & Abundant biodiversity with 186 nature reserves, with a total area of $35,500 \mathrm{~km}^{2}$ \\
\hline & \multirow[t]{8}{*}{ GXR } & Overall status & The ecological quality is fairly good \\
\hline & & WRA & Abundant water resources with a per capita level of $3,912 \mathrm{~m}^{3}$ \\
\hline & & SE & The water and soil loss occurs in only $5 \%$ of the total area \\
\hline & & SS & Soil salinization occurs in $4.7 \%$, on average, of the total area \\
\hline & & $\mathrm{LD}$ & The desertification occurs in merely $1 \%$ of the total area \\
\hline & & FD & The forest cover is $34.3 \%$ of the total area, and is increasing by $5 \%$ annually \\
\hline & & WQ/AQ & The discharge per unit GDP is relatively high \\
\hline & & $\mathrm{BD}$ & Good biodiversity with 67 nature reserves, with an area of $14,810 \mathrm{~km}^{2}$ in total \\
\hline
\end{tabular}


Table 3 continued

\begin{tabular}{|c|c|c|c|}
\hline $\begin{array}{l}\text { Sub- } \\
\text { regions }\end{array}$ & $\begin{array}{l}\text { Province, } \\
\text { municipality, } \\
\text { autonomous region }\end{array}$ & $\begin{array}{l}\text { Environmental } \\
\text { indicators }\end{array}$ & Environmental baseline levels \\
\hline \multirow[t]{40}{*}{ NW. } & \multirow[t]{8}{*}{ SXP } & Overall status & The ecological quality is poor as a whole \\
\hline & & WRA & $\begin{array}{l}\text { The available water resources are limited, with only } 57,460 \text { million } \mathrm{m}^{3} \text { in total. The per } \\
\text { capita level is } 1,557 \mathrm{~m}^{3}\end{array}$ \\
\hline & & SE & The soil and water loss occurs in as much as $64 \%$ of the total area \\
\hline & & SS & The soil salinization occurs in over $1.7 \%$ of the total area \\
\hline & & LD & The desertification occurs in $7.1 \%$, on average, of the total area \\
\hline & & FD & The forest cover is $28.7 \%$ of the total area, and is increasing by $2.3 \%$ annually \\
\hline & & WQ/AQ & $\begin{array}{l}\text { The discharge of wastewater is increasing. Air pollution is also a serious problem in } \\
\text { some cities }\end{array}$ \\
\hline & & $\mathrm{BD}$ & Moderate biodiversity with 32 nature reserves, with a total area of $70,770 \mathrm{~km}^{2}$ \\
\hline & \multirow[t]{8}{*}{ GSP } & Overall status & The ecological quality is poor as a whole \\
\hline & & WRA & The available water resources are rather limited, with a per capita level of $951 \mathrm{~m}^{3}$ \\
\hline & & SE & Has already become a serious problem \\
\hline & & SS & The soil salinization occurs in over $2.3 \%$ of the total area \\
\hline & & LD & $\begin{array}{l}\text { The desertification occurs in as much as } 55 \% \text { of the total area, with the Hexi Corridor } \\
\text { the worst case in China }\end{array}$ \\
\hline & & FD & The forest cover is as low as $4.8 \%$, with a total area of only $21,741 \mathrm{~km}^{2}$ \\
\hline & & WQ/AQ & The water and dust pollution is very serious \\
\hline & & $\mathrm{BD}$ & $\begin{array}{l}\text { Relatively poor biodiversity with only } 47 \text { nature reserves, with a total area of } \\
87,860 \mathrm{~km}^{2}\end{array}$ \\
\hline & \multirow[t]{8}{*}{ NXR } & Overall status & The ecological quality is fragile and becoming worse \\
\hline & & WRA & $\begin{array}{l}\text { Scarce water resources with a total volume of } 1,230 \text { million } \mathrm{m}^{3} \text {. The per capita level is } \\
\text { only } 212 \mathrm{~m}^{3}\end{array}$ \\
\hline & & SE & Is a rather serious problem \\
\hline & & SS & The soil salinization occurs in over $5.8 \%$ of the total area \\
\hline & & LD & The area of desertificated land is growing slowly \\
\hline & & FD & The forest cover is about $2.2 \%$ of the total area, and is increasing by $2 \%$ annually \\
\hline & & WQ/AQ & The environmental quality of water and air is, as a whole, at a good level \\
\hline & & $\mathrm{BD}$ & Relatively poor biodiversity with only 12 nature reserves, with a total area of $4,920 \mathrm{~km}^{2}$ \\
\hline & \multirow[t]{8}{*}{ XJR } & Overall status & The ecological quality is not good as a whole \\
\hline & & WRA & Water resources are limited in terms of total volume, but the per capita level is $4,767 \mathrm{~m}^{3}$ \\
\hline & & SE & The problem of water and soil loss is very serious \\
\hline & & SS & $\begin{array}{l}\text { The soil salinization occurs in as much as } 8.0 \% \text { of the total area, which is the highest in } \\
\text { China }\end{array}$ \\
\hline & & LD & Has already become a serious problem \\
\hline & & FD & The forest cover is merely $1.1 \%$ of the total area, and is increasing by $1.8 \%$ annually \\
\hline & & WQ/AQ & The environmental quality of air and water is good as a whole \\
\hline & & $\mathrm{BD}$ & Acceptable biodiversity level with 26 nature reserves, with a total area of $215,290 \mathrm{~km}^{2}$ \\
\hline & \multirow[t]{8}{*}{ IMR } & Overall status & The ecological quality is not good as a whole \\
\hline & & WRA & Lack of water resources as a whole, the per capita level is $2,082 \mathrm{~m}^{3}$ \\
\hline & & SE & The water and soil loss occurs in as much as $72 \%$ of the total area \\
\hline & & SS & The soil salinization occurs in about $6.4 \%$ of the total area \\
\hline & & LD & The desertification occurs in $30 \%$, on average, of the total area \\
\hline & & FD & $\begin{array}{l}\text { The vegetation cover is } 74 \% \text { of the total area, and the forest cover is only } 12.7 \% \text {, with } \\
\text { an increasing rate of } 0.5 \% \text { per year }\end{array}$ \\
\hline & & WQ/AQ & Air quality is good, and the WQ is poor \\
\hline & & BD & $\begin{array}{l}\text { Biodiversity loss is becoming a problem. This region has } 183 \text { nature reserves, } \\
\text { with a total area of } 148,900 \mathrm{~km}^{2} \text {. }\end{array}$ \\
\hline
\end{tabular}


Table 3 continued

\begin{tabular}{|c|c|c|c|}
\hline $\begin{array}{l}\text { Sub- } \\
\text { regions }\end{array}$ & $\begin{array}{l}\text { Province, } \\
\text { municipality, } \\
\text { autonomous region }\end{array}$ & $\begin{array}{l}\text { Environmental } \\
\text { indicators }\end{array}$ & Environmental baseline levels \\
\hline \multirow[t]{16}{*}{ QT } & \multirow[t]{8}{*}{ QHP } & Overall status & The ecological quality is not good as a whole \\
\hline & & WRA & 63,470 million $\mathrm{m}^{3}$ of water resources and $11,975 \mathrm{~m}^{3}$ per capita \\
\hline & & SE & Extensive degradation of grassland is a problem \\
\hline & & SS & The soil salinization occurs in about $3.2 \%$ of the total area \\
\hline & & LD & The desertification occurs in $16 \%$, on average, of the total area \\
\hline & & FD & $\begin{array}{l}\text { The vegetation cover is } 59 \% \text { of the total area, and the forest cover is merely } 0.4 \% \text {, with } \\
\text { an increasing rate of } 1.5 \% \text { per year }\end{array}$ \\
\hline & & WQ/AQ & The environmental quality of water and air is good \\
\hline & & BD & Vulnerable ecosystems with eight nature reserves, with a total area of $206,080 \mathrm{~km}^{2}$ \\
\hline & \multirow[t]{8}{*}{ TAR } & Overall status & The ecological quality is good in a special ecosystem. \\
\hline & & WRA & $\begin{array}{l}\text { Total volume of water resources is } 475,710 \text { million } \mathrm{m}^{3} \text {, and the per capita level is } \\
176,189 \mathrm{~m}^{3} \text {. }\end{array}$ \\
\hline & & SE & $\begin{array}{l}\text { The water and soil loss occurs in as much as } 86 \% \text { of the total area, with an area of } \\
0.9 \text { million } \mathrm{km}^{2} \text { because of the freeze-thaw effect }\end{array}$ \\
\hline & & SS & No salinization problem \\
\hline & & LD & $\begin{array}{l}\text { The desertification occurs in } 17 \% \text {, on average, of the total area, because of the grassland } \\
\text { degradation }\end{array}$ \\
\hline & & FD & $\begin{array}{l}\text { The forest and grass covers } 64.4 \% \text { of the total area, and has been recently decreasing by } \\
4 \% \text { annually }\end{array}$ \\
\hline & & WQ/AQ & No air and water pollution as a whole. \\
\hline & & BD & $\begin{array}{l}\text { The local ecosystem is vulnerable, but largely intact. Fifteen nature reserves of } \\
408,730 \mathrm{~km}^{2} \text { in area are distributed throughout the region }\end{array}$ \\
\hline
\end{tabular}

Note. WRA, SE, SS, LD, FD, WQ, AQ, and BD, see Table 1

Most of quantitative values for the ecological indicators are cited from the China Environmental Monitoring Yearbook (2004)

fragmentation; some species are already under considerable pressures. For example, the Chinese opposite angle antelope ( $P u$ Original Antelope), a species that was once widely distributed in QHP, IMR and NXR, is now restricted to the Lake Qinghai area of QHP, with a very small population of around 300 .

\section{Energy Generation Plans}

With a rapid advance in oil exploration in the Tarim Basin and other western regions, vegetation degradation and desertification in the oil exploration areas will become more serious. In turn, this will detrimentally affect nature reserves and biodiversity. Hydro-electricity development worsens the already serious condition of water and soil losses. In areas with a high incidence of natural disasters along the Yellow River of the NW sub-region, the cascade hydroelectric development will also aggravate the impacts of future destructive natural disasters. In the SW subregion, because of the karst landform development, erosion and deposition in reservoirs will increase the possibility of geological disaster. As a result, animal and plant habitats will be destroyed. Coal exploitation and utilization plans will also cause water and soil losses, air pollution, and desertification in the NW sub-region.

\section{Ecological Rehabilitation and Restoration Plans}

Ecological rehabilitation and restoration plans offer a wide range of potential benefits for ecosystems and biodiversity, such as improved land management that addresses deforestation and desertification.

Forest protection and reforestation projects will reduce surface water loss and provide better soil protection. However, in many cases natural forest systems will be replaced by single species 'economic' forests. As a result, the planned woodland structure will not enhance natural forest systems because of poor species and age diversity in the new stands.

The GWDS will provide significant support for forest and grassland ecosystems. The forests will support biodiversity by increasing the area available for important and endangered species and will improve sustainability by protecting important habitats and the ecological services they provide (Jiang and Chen 2004; Li and others 2004). 


\section{Tourism Development Plans}

In spite of the underlying importance of environmental quality for sustainability of tourism services in the region, these plans will generally have negative impacts, especially in terms of habitat loss.

The focus of tourism pressure on specific areas poses a threat of accelerated desertification. In vulnerable habitats such pressure can lead to land degradation and vegetation loss. Activities that are associated with tourism, such as woodcutting and firewood collection and hunting, forest fires will likely lead to more and increased trampling. This may damage vegetation in areas that attract tourists and lead to forest loss and habitat degradation.

Tourism developments and associated activities are likely to disturb the habitats of some animals. Impacts to key or rare species, through game hunting and harvesting of animals for restaurant food, can have a wide impact on the habitat and food chain.

\section{Overall Results of the Impact Assessment}

In order to gain an overall understanding of the stresses exerted by the GWDS on the western environment, a synthesis of the environmental impacts for each of the five KDDs has been developed. The overall results of this assessment are presented in Table 4. The information in the table shows the current status and future trends for each province and sub-region across the eight environmental indicators.
It is important to note that the GWDS is constantly evolving (future plans are not yet known) and is being implemented differently across provinces, therefore, the actual level of impact is not yet clear. In particular, the extent of environmental protection and mitigation measures remains uncertain, though many such activities have been listed in the PPPs. The summary is based on an absolute baseline analysis, under the assumption that no measures are taken to mitigate the adverse impacts. The symbols in the table indicate current status and potential positive or negative consequences related to the GWDS.

Recommendations

Based on the SEA results of the GWDS, the following recommendations have been developed for immediate use and with the hope they will serve as an environmental safeguard.

\section{Policy Suggestions on Transformation of the Western Development}

Several problems are identified with the western economic development. The first is the stress from an old-fashioned industrial structure, which has led to severe resource waste and exhaustion of resources. The second is unenlightened investment. Authorities in many western areas subscribe to the idea of 'pollution first - treatment afterwards', which means they accept environmental damage in the initial stage of development. For example, many western cities

Table 4 Ecological baseline levels and future trends in the western sub-regions and provinces under the stresses of the GWDS

\begin{tabular}{|c|c|c|c|c|c|c|c|c|c|c|c|c|c|c|c|c|}
\hline & \multicolumn{2}{|c|}{ WRA } & \multicolumn{2}{|l|}{$\mathrm{SE}$} & \multicolumn{2}{|l|}{ SS } & \multicolumn{2}{|l|}{ LD } & \multicolumn{2}{|l|}{ FD } & \multicolumn{2}{|l|}{ WQ } & \multicolumn{2}{|l|}{ AQ } & \multicolumn{2}{|l|}{$\mathrm{BD}$} \\
\hline & Now & Future & Now & Future & Now & Future & Now & Future & Now & Future & Now & Future & Now & Future & Now & Future \\
\hline SW & I & $\nearrow$ & III & $\searrow$ & I & $\nearrow$ & I & $\nearrow$ & III & $\nearrow$ & III & $\nearrow$ & II & $\searrow$ & III & $\searrow$ \\
\hline CQM & II & $\rightarrow$ & III & $\searrow$ & I & $\rightarrow$ & I & $\rightarrow$ & III & $\nearrow$ & III & $\nearrow$ & III & $\rightarrow$ & II & $\searrow$ \\
\hline SCP & I & $\nearrow$ & III & $\searrow$ & I & $\nearrow$ & I & $\rightarrow$ & III & $\nearrow$ & II & $\nu$ & II & $\searrow$ & III & $\nearrow$ \\
\hline YNP & I & $\nearrow$ & III & $\searrow$ & I & $\nearrow$ & I & $\nearrow$ & III & $\nearrow$ & III & $\nearrow$ & II & $\rightarrow$ & III & $\nearrow$ \\
\hline GZP & I & $\searrow$ & III & $\searrow$ & I & $\rightarrow$ & I & $\nu$ & III & $\nu$ & III & $\nearrow$ & III & $\searrow$ & II & $\searrow$ \\
\hline GXR & II & $\nearrow$ & I & $\searrow$ & I & $\nearrow$ & I & $\rightarrow$ & III & $\searrow$ & II & $\nu$ & II & $\nearrow$ & III & $\searrow$ \\
\hline NW & III & $\searrow$ & III & $\nearrow$ & III & $\searrow$ & III & $\nu$ & III & $\nu$ & II & $\searrow$ & II & $\nearrow$ & II & $\searrow$ \\
\hline SXP & II & $\searrow$ & III & $\nearrow$ & III & $\searrow$ & III & $\nearrow$ & III & $\nearrow$ & II & $\searrow$ & II & $\nearrow$ & II & $\searrow$ \\
\hline GSP & III & $\searrow$ & III & $\searrow$ & III & $\searrow$ & III & $\searrow$ & III & $\searrow$ & II & $\searrow$ & III & $\nearrow$ & II & $\searrow$ \\
\hline NXR & III & $\searrow$ & III & $\nearrow$ & III & $\searrow$ & III & $\nu$ & III & $\searrow$ & III & $\nearrow$ & III & $\searrow$ & III & $\rightarrow$ \\
\hline XJR & III & $\searrow$ & I & $\rightarrow$ & III & $\searrow$ & III & $\rightarrow$ & III & $\nearrow$ & I & $\nearrow$ & I & $\rightarrow$ & II & $\nearrow$ \\
\hline IMR. & II & $\searrow$ & III & $\searrow$ & III & $\rightarrow$ & III & $\nu$ & III & $\nu$ & II & $\nu$ & I & $\searrow$ & III & $\searrow$ \\
\hline QT & I & $\rightarrow$ & II & $\searrow$ & II & $\rightarrow$ & III & $\rightarrow$ & II & $\nearrow$ & I & $\searrow$ & I & $\rightarrow$ & I & $\searrow$ \\
\hline TAR & I & $\rightarrow$ & III & $\searrow$ & I & $\rightarrow$ & III & $\rightarrow$ & II & $\rightarrow$ & I & $\searrow$ & I & $\rightarrow$ & I & $\searrow$ \\
\hline QHP & I & $\rightarrow$ & I & 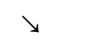 & III & $\rightarrow$ & III & $\rightarrow$ & II & $\nearrow$ & I & $\nu$ & I & $\rightarrow$ & II & $\rightarrow$ \\
\hline
\end{tabular}

Note. WRA, SE, SS, LD, FD, WQ, AQ, BD, $\rightarrow$, \, and $\nearrow$, see Table 1 
welcome without any wise tradeoffs the decaying industries transferred from the eastern part of China that pollute the environment and give low value added. The third problem is that the reforestation policy is not flexible enough to respond to local conditions. This is especially true in the arid or semi-arid areas where too much forest land is planned in places where grassland is more suitable.

In order to address these problems at the policy level, it needs to be stressed that ecological restoration and environmental protection should be the prime tasks of the GWDS. Society should increase the percentage of investment for these purposes. Policies for land use, including reforestation, should be adapted to local conditions. An incentive policy should be adopted to promote the industries based on the use of desert plants. In addition, policies for land use should be based on an integrated perspective where poverty concerns, forestry growth and environmental concerns are considered jointly. Special emphasis should be given to combining ecological recovery with poverty alleviation.

\section{Priority Areas for Mitigation}

The most pressing needs for mitigation are the areas where negative impacts are anticipated from a situation with significant (Grade III) or moderate (Grade II) environmental problems.

These key areas for mitigation priority are listed by subregions in Table 5. In the table, the areas are further singled out and related to the most important KDD plans. As can be seen, in the SW sub-region the main challenges are soil erosion caused primarily by land-use plans and energy resource exploitation plans. Loss of biodiversity is caused by the same two plans and the water resources plan.

A secondary priority is the downward trend in AQ resulting from energy-related activities. Secondary challenges include WQ and loss of biodiversity. Compared with the NW sub-region and the SW sub-region, the QT sub-region has no Grade III areas of mitigation. However, in the QT sub-region, there is a negative trend in soil erosion and a significant desertification problem.

\section{Principles for Safeguarding the Ecological Security of Western China}

In order to maintain ecological security of western China, the following safeguarding principles need to be set up and enforced during the implementation of the GWDS.

In key ecological function areas, any development and construction activities that may cause serious degradation of ecological functions shall be prohibited. Unenlightened exploitation and overgrazing should be avoided to ensure bio-security and to prevent grassland degradation. Indiscriminate wasteland reclamation should be prohibited to prevent land degradation. The selection of sites and routes for hydropower and transportation projects has to focus on protecting biodiversity, natural landscapes, ecologically fragile areas and historical relics.

In arid and semi-arid regions, land reclamation and agricultural development projects that may increase the volume of water diversion should be kept under strict control. New projects with high water consumption should be carefully considered and the transferal of water rights from farming to industrial use should be carried out prudently. In areas with prominent problems in water ecosystems, new water impoundment, water diversion and irrigation projects that may aggravate declines in water resources should be halted. Water-saving irrigation and efficient agricultural projects should be developed. The principle of 'development scales complying with available water resource' should always be upheld to protect WQ, ensure water use based on ecological principles and to prevent land salinization.

In mining development, oil and gas exploration and exploitation, as well as the construction of transportation and pipeline transport projects, groundwater sources should be protected and excavation areas should be reduced. Newly built mining development projects which may

Table 5 Determination of the prioritized mitigation areas with the KDDs based on overall assessment results for the three sub-regions

\begin{tabular}{|c|c|c|c|c|c|c|c|c|}
\hline \multirow[t]{2}{*}{ Sub-regions } & \multicolumn{8}{|c|}{ Environmental indicators } \\
\hline & WRA & SE & SS & LD & FD & WQ & AQ & $\mathrm{BD}$ \\
\hline SW & & $\begin{array}{l}\text { (III) } \searrow \\
\text { Land/water }\end{array}$ & & & & & $\begin{array}{l}\text { (II) } \searrow \\
\text { Energy }\end{array}$ & $\begin{array}{l}\text { (III) } \searrow \\
\text { Energy/tourism }\end{array}$ \\
\hline NW & $\begin{array}{l}\text { (III) } \searrow \\
\text { Water/Land/ Energy }\end{array}$ & & $\begin{array}{l}\text { (III) } \searrow \\
\text { Water/land }\end{array}$ & $\begin{array}{l}\text { (III) } \searrow \\
\text { Land/energy }\end{array}$ & $\begin{array}{l}\text { (III) } \searrow \\
\text { Land/energy }\end{array}$ & $\begin{array}{l}\text { (II) } \searrow \\
\text { Water/energy }\end{array}$ & & 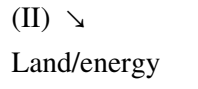 \\
\hline QT & & $\begin{array}{l}\text { (II) } \searrow \\
\text { Land/water }\end{array}$ & & & & & & \\
\hline
\end{tabular}

Note. WRA, SE, SS, LD, FD, WQ, AQ, BD, $\rightarrow, \nearrow$ and $\searrow$, see Table 1 
produce severe ecological impacts should be kept under strict control.

\section{Discussion}

The vast scale and a lack of systematic monitoring have made the GWDS SEA prohibitively difficult to accomplish in one comprehensive SEA. This preliminary SEA has a dual role. One role is to evaluate environmental impacts of the firstphase plans of the GWDS, and to make recommendations for the refining of plans still being drafted. A related objective is to promote a discussion that leads to and guides the implementation of the released plans in an ecologically friendly way. The other role is to develop new techniques or methods for Chinese SEA and to accumulate information from the related experiences. Like those in other countries, Chinese SEAs are often carried out simply by employing project EIA methods (Partidario 2000; Zhu and others 2005; Chaker and others 2006). This problem has become one of the most significant barriers to SEA or PEIA effectiveness in China (Barker 2006; Tang and others 2007). In our case, a combination of three methods, matrix assessment, incorporation of expert judgment and trend analysis, was adopted in the assessment process. The findings were subject to approval based on broad consultations. Our attempt demonstrates that such an integrative use of a policy-analysis orientation and EIA based methods may help to overcome the above-mentioned challenges in a large-scale SEA, such as this one.

Lack of public participation has been impairing the effectiveness of SEA in China (Zhu and others 2005; Chen and others 2007; Zhou and Sheate 2009; Liu and others 2010). The SEA of the GWDS shows that it is not necessary to develop a complex public consultation process; what is important is to involve key stakeholders who play critical roles in the decision processes. Thus, officials and experts from several relevant departments were involved in the SEA process through a series of brainstorming workshops and round table debates. In this way important consensuses were achieved based on a definite respect for the first principle of ecological security that was set up in the initial meeting of the SEA process. All of those efforts helped to increase the awareness of and support for the use of the SEA process, improved inter-agency cooperation, and, more importantly, led to the adoption of recommendations or suggestions produced by the SEA. Furthermore, it can be concluded that constructing an overriding negotiation principle or ground rule that is accepted by all key stakeholders at the beginning is critical to ensure success of public participation in a multi-layered SEA. Otherwise, wasted time and budgetary resources could not be easily avoided. Furthermore, expressions of opinions would likely be chaotic and undirected.
The GWDS is a long term development strategy with a phased decision process during the period from 2000 to 2050. There will be more concrete SEAs for later decision processes under the framework of the GWDS. The forthcoming SEAs will review the last phase (usually a five-year period) implementation of the GWDS in a way that concentrates on environmental problems and ecological rehabilitation. They will also evaluate the environmental impacts of newly proposed planning or plans for the next phase in order to formulate new concrete environmental countermeasures and recommendations. However, in this assessment we found that the SEA capacity at and below the provincial level was rather weak. If this problem cannot be promptly handled, the effectiveness of SEA or PEIA would be in absolute doubt during the rapid western development. Therefore, an SEA capacity building plan should be developed along with the ensuing SEA practice under the framework of the GWDS. The purpose would be to improve the awareness and technical skills of decisionmakers, environmental officials and SEA technicians, especially at the grassroots level.

\section{Conclusions}

The GWDS is a document containing government statements aimed at the establishment of a 'new western China' over the coming decades. An additional objective is to promote development for ethnic minorities so that they will be better integrated with the rest of China. The SEA of the GWDS is designed to support multi-level decision-making and a strategic priority setting process by providing expert guidance and informed recommendations for later stages of the GWDS implementation plans. It is intended to create an awareness among GWDS planners potential issues and major environmental challenges that lie ahead.

The SEA focuses on analyzing the environmental impacts of five KDDs of the GWDS. It has been found that much of the environment and natural resource base in western China is vulnerable to human pressure. Planned activities in the KDDs are likely to place more pressure on the region's water resources. High water exploitation levels in the NW sub-region is a serious threat in the area. Strategic plans for agricultural expansion and urbanization will lead to an increase in water demand in a place where water is already scarce. While forest coverage has been increasing, there are significant questions about the quality of forests that are being established with poor age structures and species compositions. The most significant air pollution problems arise from the plans for expanding coal and oil extraction industries. Therefore, the immediate actions and tailored countermeasures should be planned to promote a sustainable future with a special focus on mitigation 
priorities in the three sub-regions to safeguard the overall ecological security of western China. These ecological safeguarding principles and environmental permission requirements should be highlighted when formulating detailed development plans or introducing projects in each western province.

One of the chief objectives of the SEA was to influence the national and sectoral decision-making processes by providing an early warning of the need to safeguard ecological security. In this SEA, the potential effects of the known plans and planned large projects on ecological security were analyzed. Through intensive discussions with key stakeholders during the evaluation process, mitigation measures were formulated to minimize adverse impacts. It is encouraging that in recent implementation of the GWDS plans the relevant managers have adopted some important recommendations. These include zoning preservation of ecological functions, building up biodiversity corridors to link important habitats, optimizing industrial development scales based on available water resources and by placing a priority on ecological water use, and prohibiting a transfer of the decaying industries to the west from the east. It is expected that the more concrete SEAs of later GWDS decision processes will continue to contribute to ecological security for building up a new western China.

Acknowledgments This study was developed through collaboration between the Foreign Economic Cooperation Office (FECO), MEP of China and the World Bank. Guidance for the project was given by Jostein Nygard and Madga Lovei of the World Bank. International experts Rob Verheem and Arend Kolhoff from the Netherlands Commission for EIA and Haakon Vennemo from ECON in Norway provided technical assistance throughout the process, together with domestic consultants Dr. Zhang Yan, Dr. Zhao Yanwei and Dr. Sui Xin at Beijing Normal University. We are grateful for the contributions of all these people to this SEA study. Special thanks are given to the anonymous reviewers of the manuscript for their incisive and comprehensive comments, and also to emeritus Prof. Robert B. Wenger from the University of Wisconsin-Green Bay for his kind help in providing stylistic and grammatical improvements to the manuscript.

Open Access This article is distributed under the terms of the Creative Commons Attribution Noncommercial License which permits any noncommercial use, distribution, and reproduction in any medium, provided the original author(s) and source are credited.

\section{References}

Bao CK, Lu YS, Shang JC (2004) Framework and operational procedure for implementing strategic environmental assessment in China. Environmental Impact Assessment Review 24:27-46

Barker A (2006) Strategic Environmental Assessment (SEA) as a tool for integration within coastal planning. Journal of Coastal Research 22:946-950

Bina O (2008) Context and systems: thinking more broadly about effectiveness in strategic environmental assessment in China. Environmental Management 42:717-733
Briffett C, Obbard JP, Mackee J (2003) Towards SEA for the developing nations of Asia. Environmental Impact Assessment Review 23:171-196

Chaker A, El-Fadl K, Chamas L, Hatjian B (2006) A review of strategic environmental assessment in 12 selected countries. Environmental Impact Assessment Review 26:15-56

Chen QL, Zhang YZ, Ekroos A (2007) Comparison of China's environmental impact assessment (EIA) law with the European Union (EU) EIA Directive. Environmental Monitoring and Assessment 132:53-65

Chen CH, Wu RS, Liu WL (2009) Development of a methodology for strategic environmental assessment: application to the assessment of Golf Course Installation Policy in Taiwan. Environmental Management 43:166-188

Díaz M, Illera JC, Hedo D (2001) Strategic environmental assessment of plans and programs: a methodology for estimating effects on biodiversity. Environmental Management 28:267-279

Fischer TB (2003) Strategic Environmental Assessment in postmodern times. Environmental Impact Assessment Review 23:155-170

Fischer TB, Gazzola P (2006) SEA effectiveness criteria-equally valid in all countries? The case of Italy. Environmental Impact Assessment Review 26:396-409

Geneletti D, Bagli S et al (2007) Spatial decision support for strategic environmental assessment of land use plans. A case study in southern Italy. Environmental Impact Assessment Review 27:408-423

Jiang El, Chen ZJ (2004) On the objectives, roles and policies of returning arable land to forest in Western China. Journal of Beijing Forestry University 3(2):23-26

Li CH, Yang ZF, Guo QY (2003) The influence of Yellow River Laxiwa hydropower station on regional landscape. Journal of Safety and Environment 3(2):27-30

Li L, Liu LM, Xie HL (2004) Estimates on soil conservation effects and eco-economic value brought by projects to return arable land to forest and grassland. Journal of Water and Soil Conservation 18(1):161-167

Liu Y, Chen JN, He WQ, Tong QY, Li WF (2010) Application of an uncertainty analysis approach to strategic environmental assessment for urban planning. Environmental Science \& Technology 44:3136-3141

Ministry of Environmental Protection of the People's Republic of China (2007) Ecological Function Zoning of China. China Environmental Science Press, Beijing

Ministry of Environmental Protection of the People's Republic of China, State Bureau of Surveying and Mapping of the People's Republic of China (2002) Atlas of Remote Sensing Investigation on EcoEnvironment in Western China. China Science Press, Beijing

National Bureau of Statistics of China (2004) China Statistical Year book. China Statistics Press, Beijing

Noble BF (2004) Integrating strategic environmental assessment with industry planning: a case study of the Pasquai-Porcupine forest management plan, Saskatchewan, Canada. Environmental Management 33(3):401-411

Noble BF, Christmas LM (2008) Strategic environmental assessment of greenhouse gas mitigation options in the Canadian Agricultural Sector. Environmental Management 41:64-78

Partidario MR (2000) Elements of an SEA framework-improving the added value of SEA. Environmental Impact Assessment Review 20:647-663

Randazzo G, Curzio ML, Lanza S (2008) First steps in strategic environmental assessment (SEA) adoption for coastal planning in Sicily (South Italy). Journal of Coast Conservation 12:161-168

Risse N, Crowley M, Vincke P, Waaub J (2003) Implementing the European SEA Directive: the member states' margin of discretion. Environmental Impact Assessment Review 23:453-470 
Salhofer S, Wassermann G, Binner E (2007) Strategic environmental assessment as an approach to assess waste management systems. Experiences from an Austrian case study. Environmental Modeling \& Software 22:610-618

Say NP, Yücel M (2006) Strategic environmental assessment and national development plans in Turkey: towards a legal framework and operational procedure. Environmental Impact Assessment Review 26:301-316

Shen ZY, Ding XW, Yang ZF (2004) Construction of plan environmental impact assessment system in China. Journal of Environmental Informatics 4:75-82

Sinclair AJ, Sims L, Spaling H (2009) Community-based approaches to strategic environmental assessment: lessons from Costa Rica. Environmental Impact Assessment Review 29:147-156
Tang T, Zhu T, Xu H (2007) Integrating environment into land-use planning through strategic environmental assessment in China: towards legal frameworks and operational procedures. Environmental Impact Assessment Review 27:243-265

Therivel R, Walsh F (2006) The strategic environmental assessment directive in the UK: 1 year onwards. Environmental Impact Assessment Review 26:663-675

Zhou KY, Sheate WR (2009) Comparative analysis of SEA legal requirements and institutional structure in China (Mainland), Canada and the UK (England). Journal of Environmental Assessment Policy and Management 11(4):387-426

Zhu T, Wu J, Chang I (2005) Requirements for strategic environmental assessment in China. Journal of Environmental Assessment Policy and Management 7(1):81-97 